\title{
Molecular Heterogeneity of Type 2 Diabetes Mellitus in Mexican Population and its Impact of the Public Health on Policies in Primary Care
}

Luis Javier Flores-Alvarado ${ }^{1}$, Sergio Alberto Ramirez-Garcia ${ }^{*}$, Pedro Duran Ferman ${ }^{3}$, Nory O Davalos-Rodriguez ${ }^{1,4}$, Claudia Chavéz-Lopez ${ }^{5}$ Jareth Marco Cruz-Bastida ${ }^{6,7,9}$, Carlos Alberto García-Aguila ${ }^{7,8}$ and Carlos Enrique Cabrera Pivaral ${ }^{9}$

${ }^{1}$ Programa de Doctorado en Genética Humana. Departamento de Biología Molecular y Genómica del Centro Universitario de Ciencias de la Salud, Benemérita Universidad de Guadalajara, Jalisco, México

${ }^{2}$ Centro de Investigación en Nutrición y Alimentación. Universidad de la Sierra Sur, Sistema de Universidades Estatales de Oaxaca (SUNEO), Miahuatlán de Porfirio Díaz, Oaxaca, México

${ }^{3}$ Dirección de la División de Estudios de Postgrado. Universidad de la Sierra Sur, Sistema de Universidades Estatales de Oaxaca (SUNEO), Miahuatlán de Porfirio Díaz, Oaxaca, México

${ }^{4}$ Instituto de Genética Humana, Dr. Enrique Corona Rivera. . Departamento de Biología Molecular y Genómica del Centro Universitario de Ciencias de la Salud, Benemérita Universidad de Guadalajara, Jalisco, México

${ }^{5}$ Programa de Maestría Salud Pública de la División de Estudios de Postgrado. Universidad de la Sierra Sur, Sistema de Universidades Estatales de Oaxaca (SUNEO), Miahuatlán de Porfirio Díaz, Oaxaca, México

${ }^{6}$ Licenciatura en Derecho y Ciencias Sociales. Universidad Regional del Sureste (URSE), Oaxaca de Juárez, México

${ }^{7}$ Programa de Incorporación a la Investigación Temprana en Ciencias Sociales y Biomédicas. Grupo de Estudio Multidisciplinario para el Estudio Integral de las Enfermedades Metabólicas e Infecciosas en población Mexicana

${ }^{8}$ Carrera de Médico Cirujano y Partero. . Departamento de Biología Molecular y Genómica del Centro Universitario de Ciencias de la Salud, Benemérita Universidad de Guadalajara, Jalisco, México

${ }^{9}$ Centro de Investigación en Desarrollo Social. . Departamento de Biología Molecular y Genómica del Centro Universitario de Ciencias de la Salud, Benemérita Universidad de Guadalajara, Jalisco, México

\begin{abstract}
Type 2 diabetes mellitus is a complex disease and a global health problem; hence the first level of health care should handle the approaches of medical genetics to reduce its incidence. In this manuscript we present perspectives of the study of genomic medicine carried out in Mexican population, which show a molecular heterogeneity according to the studied population. Genes currently associated to diabetes are fifty, including $A B C A 1, A P O E, B G L A P, L R P 2$, CYP19A1, hIAPP, SCARB1, TCF7L2, TNFA. Up to date there are no variants related to diabetes mellitus in the HNF1 $\beta$, INS, and NEUROD1 among other genes. In relation to chronic complications of DM2, the genes ACE, ADRB3, APOE, CUBN, hANP, LRP2 and HPSE are analyzed.
\end{abstract}

Keywords: Polygenic; Threshold; Complex disease; Type 2 diabetes

Abbreviations: TDM: Type of Diabetes Mellitus; HLA: Histocompatibility Leukocyte Antigen; MODY: Onset Diabetes in the Young mature. SNP: Single Nucleotide Polymorphisms; ORR: Odds ratio; GM: Genomic Medicine; PH: Public Health

\section{Diabetes Mellitus Complexity}

In today's post-genomic era of medicine, it is important that the family doctor at the first level of health care, know the impact of genomics and medical genetics on clinical practice of common diseases, such as type 2 diabetes mellitus (T2DM) $[1,2]$.

Especially in order to make an accurate diagnosis and can lead to a precise prescription therapeutic, considering the molecular mechanisms that influence response to treatment. So in this sense physician must understand first, that the T2DM is a complex trait with threshold. This concept is defined as the threshold for the phenotype being expressed, or the addition factors for the expression of the trait. Otherwise, the combination of the additive effect of loci plus the environmental factors, which are inherent in each population studied, permits the full expression of that trait (Figure 1) [1,2]

Taking into account this model, when comparing probands with a parent affected against general population, the susceptibility increased. This also is observed in the index case sporadic against the familial cases, with greater weight of genetics that predispose to its occurrence. Individuals who have a high genetic risk exceeded threshold despite having little exposure to environmental factor. In contrast, individuals, who have exposed to high environmental burden and little genetic risk, also reached the threshold resulting in manifestation of the trait $[1,2]$

Then in this context, the genetic variations, such as polymorphisms are the predisposing units, or risk factors; mutations are directly responsible for this phenotype [1,2]. But in the case of complex diseases, such as T2DM, mutation in one gene occur in few families, so in these cases, major gene determines the phenotype. Also, polygenic component could be found in minor genes, whose additive effect determines the trait $[1,2]$.

In accordance to what has been said, the multifactorial nature of T2DM is reflected in the low rates of concordance of monozygotic and dizygote twins, as well as in the familial aggregation without presenting a single pattern of inheritance. The low penetrance, genetic variation, genetic heterogeneity, and genomic imprinting also explain the lack of an inheritance pattern $[3,4]$.

Low penetrance means that an individual having the genotype for T2DM, but a low probability of developing it. While the genetic variation, show that variants at the sequence of genes, do not produce directly the disease, but some alleles predispose to the trait, while others ones are protective factors for the development. We take much care to

*Corresponding author: Sergio Alberto Ramirez Garcia MD, MSc, PhD, Calle Guillermo Rojas Mijangos S/N, Esq. Av. Universidad Col. Ciudad Universitaria, Miahuatlán de Porfirio Díaz, Oaxaca., México C.P. 70800, Tel/Fax: 01(376) 76 5-23-25; E-mail. sergio7gentica@hotmail.com

Received October 02, 2014; Accepted December 16, 2014; Published Decembe 18,2014

Citation: Flores-Alvarado LJ, Ramirez-Garcia SA, Ferman PD, Davalos-Rodriguez NO, Chavéz-Lopez C, et al. (2014) Molecular Heterogeneity of Type 2 Diabetes Mellitus in Mexican Population and its Impact of the Public Health on Policies in Primary Care. Med chem 4: 791-797. doi:10.4172/2161-0444.1000232

Copyright: () 2014 Flores-Alvarado LJ, et al. This is an open-access article distributed under the terms of the Creative Commons Attribution License, which permits unrestricted use, distribution, and reproduction in any medium, provided the original author and source are credited. 
Citation: Flores-Alvarado LJ, Ramirez-Garcia SA, Ferman PD, Davalos-Rodriguez NO, Chavéz-Lopez C, et al. (2014) Molecular Heterogeneity of Type 2 Diabetes Mellitus in Mexican Population and its Impact of the Public Health on Policies in Primary Care. Med chem 4: 791-790. doi:10.4172/2161-0444.1000232

emphasize this point; one gene variation cannot explain the increased incidence of DM2 observed, but it explains, the ratio of epistasis between the loci involved, according to what expected for multifactorial disorders.

In this context, there have been more than 50 genes associated with $\mathrm{T} 2 \mathrm{DM}$ in different populations, involving multiple molecular pathways, which in terms of haplotypes are translated in a combination or heterogeneity molecular mechanisms. These have been extensively described in various publications. In this paper we only analyze genes related to Mexican population, which more than twenty genes are associated to T2DM (Table 1) [3,4].

Although there are many genes involved as risk factors for T2DM, also a single gene can have variants of risk and protection, closely related to the frequency of alleles in the population and is part of the molecular heterogeneity; however some genes suffer genetic reprogramming known as imprinting. This is influenced by chemical changes such as methylation and acetylation, among others. This represents part of the field of epigenetic. The impact of this should be studied in relation to the clinic phenotype en T2DM. Some genes involved in the development of type 2 diabetes in Mexicans such as insulin and heparanase are regulated by methylation pattern $[1,3]$.

There are varying aspects also related to T2DM such as a complex trait, the clinically presentation, pattern of inheritance, age of onset, environmental factors, geographical distribution (differences in frequency in different ethnic groups), insulin secretion pattern, association with cardiovascular risk factors with obesity and insulin resistance [3].

Thus the delineation of the T2DM phenotype includes establishing the differential diagnosis with monogenic disorders of glucose homeostasis and chromosomal syndromes, which are not diagnosed by the lack knowledge of them [1].

The complexity of type 2 diabetes mellitus also lies in the phenocopy which are associated with environmental factors, or overlapped with different types of diabetes (Figure 1). However six pure forms of TDM have been recognized: T1DM, T2DM, TDM with deaf, TDM MODY, TDM in the elderly and neonatal DM (permanent and transitory) (Figure 1). T1DM and T2DM have a complex inheritance pattern; TDM with deafness has a mitochondrial transmission and the last three
TDM's are inherited with an autosomal dominant pattern [3,4].

T1DM and T2DM are well known as complex trait, but the environmental triggers are different. T1DM is elicited mainly by toxins and viral infections, whereas T2DM are produced by metabolic alterations. In T1DM familial aggregation can be explained by the HLA class I and II genes. The etiology of this entity is caused by destruction of pancreatic beta cells which leads to insulin deficiency. An antibody against glutamic acid decarboxylase and insulin receptor also explains the insulin deficiency observed [3,5].

On the other hand, the pathogenesis of the T2DM, is related to insulin resistance (IR), due to beta cell dysfunction, hepatic damage, endothelial dysfunction, alterations of the hypothalamic-pituitary, lipotoxicity, glucotoxicity, oxidative stress, energy imbalance, defects of incretine system, among others. In this sense, therefore many genes associated with this metabolic pathways, are involved in the predisposition of T2DM. Consequently the threshold is modulated by the additive effect of polymorphisms at different loci, plus environmental factors [5-7].

However it is essential to analyze pedigrees of families who develop antibodies characteristic of T1DM in families with T2DM and also T2DM families with mitochondrial component (Figure 1). In Mexican population it has been described an entity named MODY with antibody production characteristic of T1DM. The frequency of co-inheritance of those two forms is not known. The phenotype of the MODY form is related to an early onset of age: for example combined TDM-MODY with T2DM, results in neonatal DM [3,8-11]. Setting this complexity partly explains the differences in response to drug treatment.

The family physician should consider that, in the context of multifactorial diseases such as the threshold for T2DM. Much has been made on the interaction of genes and environment in the development of T2DM [3].

However even in the Mexican population there have not been studies to outline the overlapping forms that we can found even in the same family, in order to set the threshold, where environment and genetic factors are crucial. This field will be part of the future work in México and certainly limits a more personalized medicine in the care of the diabetic patient.

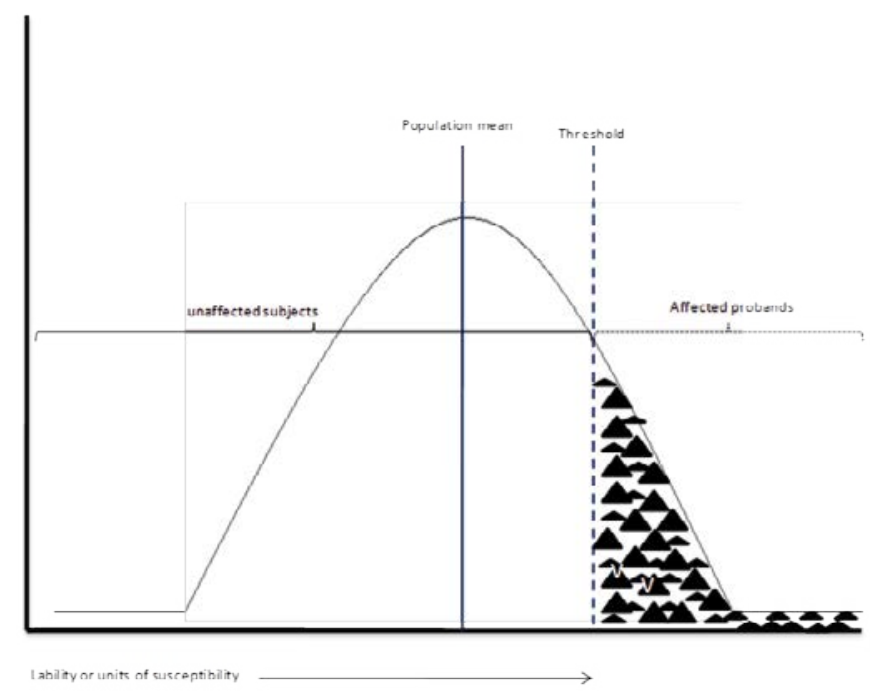

Figure 1: Threshold Model for Type 2 Diabetes Mellitus. Probands unaffected no evidence of increased genetic or environmental predisposition are represented in the pre-dotted line representing the threshold area. While those who are affected are represented in the image filled with triangles 
Citation: Flores-Alvarado LJ, Ramirez-Garcia SA, Ferman PD, Davalos-Rodriguez NO, Chavéz-Lopez C, et al. (2014) Molecular Heterogeneity of Type 2 Diabetes Mellitus in Mexican Population and its Impact of the Public Health on Policies in Primary Care. Med chem 4: 791-790. doi:10.4172/2161-0444.1000232

\begin{tabular}{|l|l|}
\hline \multicolumn{1}{|c}{ Metabolic pathway } & \multicolumn{1}{c}{ Associted genes } \\
\hline Adipocyte funtion and lipid metabolism & ABCG1, APOE, ADRB3, CYP19A1,FABP2, LEPR, LRP2, MTP, PPARG \\
\hline Beta cell dysfunction of the pancreas & CPN10, HNF4A, TCF1, SUR1, KIR6.2, SLCA2A, UCP2, IAPP, INS, GCK, SIRT1,ARNT, FOXO1, NNT \\
\hline Cell cycle regulators & HHEX1/IDE, CDKAL1, CDK2A/B, CDC123/CAMKLD, TSPAN8, THADA, PALGPS2 \\
\hline Cytoesqueleton and extracelular matrix & ADAMTS9, ARHGEF11, ELMO1, NXPH1 \\
\hline Energetic Balance & PGC1, SIRT1, UCP2 \\
\hline Incretin system & DPPIV, GLP1, GIP, KCNQ1,KCNJ11 \\
\hline Inflamation & ADIPOQ, HLA-G, IL-6, TNFA \\
\hline Liver funtion & GYS1, GCGR, IGF1, IGFBP2, HNF1A \\
\hline Mechanism of insulin in tissue & ATXN2, ATXN3, ENPP1, FTO, INSR, IRS1, IRS2, PIK3,PP1R3A, RBP4 \\
\hline Morphogensis of the pancreas & FOXO1,FOXA2, JAZF1, NOTCH2, RORA,TCF7L2 \\
\hline Proteosome & UBQLNL \\
\hline Trace elements and mineral metabolism & SLC30A8 \\
\hline Transporters to aromatic aminoacids & SLC16A11, SLC16A13 \\
\hline Vascular and hypothalamic disfuntion & ELMO1, HPSE, HPSG, ICF7L2, NOS3, NXPH1 \\
\hline
\end{tabular}

Table 1: Major genes associated with type 2 diabetes mellitus

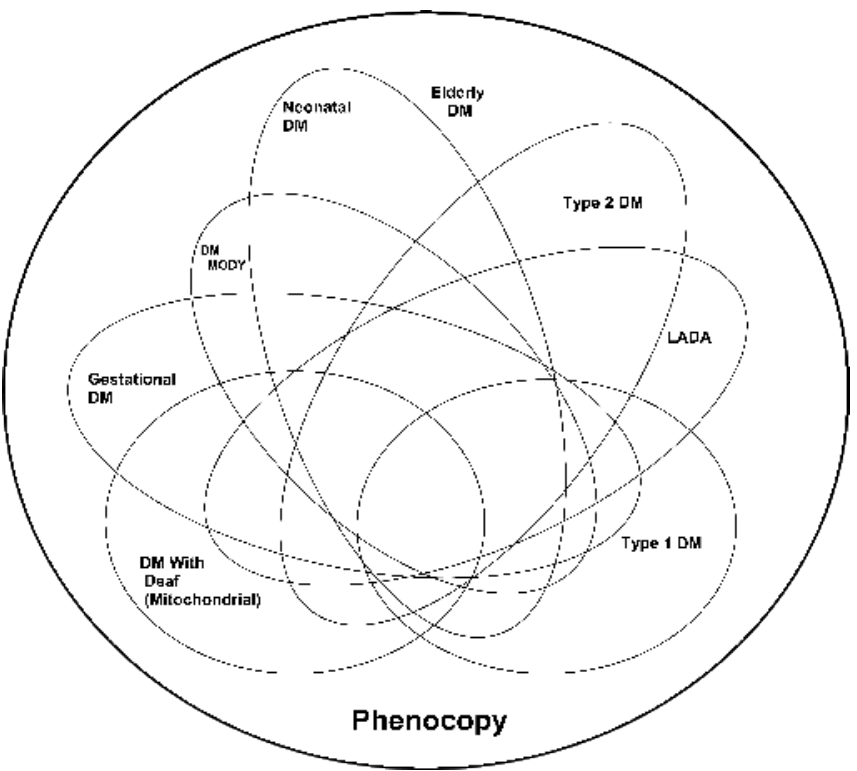

Figure 2: Co-inheritance of T2DM and overlapping with multifactorial variants as type 1 DM, LADA and gestational, and with phenocopy, as part of the complexity of T2DM.

\section{T2DM Molecular Heterogeneity in Mexican Population}

Previous studies in Mexican population showed heterogeneity, and different genes related to metabolic pathways are associated with diabetes. In patients from the City of Mexico, the polymorphism $\mathrm{T}>\mathrm{C}$ in the codon 230 of $A B C A 1$ gene (sterol transport gene type 1), is associated with early-onset (age before 45 years) [12]. Also is involved in the glyburide response to treatment [13].

Whereas variations in CPN10 gene (encodes for calpain-10, muscle protease) are found in patients with T2DM from a population of southeast and Center of México [14]. Its haplotype 112/121 is conformed by alleles SNP-19, SNP63. It is interesting that this phenotype is not associated in patients from Western of México [15]. The homozygote $\mathrm{G}$ of SNP43 also explains the odds ratio in population of the State of Jalisco (West México) [16].

The gene TCF7L2 (encodes for the transcription factor) is very important for the pancreatic beta cells morphogenesis; their polymorphisms rs12255372 and DG105478 are associated with T2DM in a population of Center of México [17].
Other markers are analyzed in this population and predisposition to the locus LOC387761 and polymorphism p.Gli972Arg of IRS1 (insulin receptor substrate 1) and its interaction with MGEA5 gene were found (meningioma expressed antigen type 5) [17-20].

Studies in the Western of Mexico have found several genes related to the development of T2DM. Those genes are implicated in different metabolic pathways concerning to lipid metabolism, such as APOE, SCARB1, TNFA. The heterocygote genotypes E3/E2, T188G polymorphism in APOE and SCARB1 gene (cluster CD36 in foamy macrophages) respectively, as well as haplotype GA in the promoter region of TNFA genes, are associated to T2DM [21-23].

It has also been used in population from Jalisco state, variants as risk factor for diabetes, such as CYP19A1 gene (encodes for aromatase, enzyme by the estrogen synthesis). It has found that the allele $\mathrm{F}$ from repeated (TTTA)n, is present in four percent of patients. Also the haplotype constructed with polymorphisms p.G33A, p.P207S and p.R265C are associated with increased levels of glucose. Although individually, heterozygote carriers for p.P207S shown an over dominant 
Citation: Flores-Alvarado LJ, Ramirez-Garcia SA, Ferman PD, Davalos-Rodriguez NO, Chavéz-Lopez C, et al. (2014) Molecular Heterogeneity of Type 2 Diabetes Mellitus in Mexican Population and its Impact of the Public Health on Policies in Primary Care. Med chem 4: 791-790. doi:10.4172/2161-0444.1000232

effect.This polymorphism leads to a conformational change in the protein. The impact on the functionality should be explored in future in vitro studies and also impact on the diabetes clinic phenotype [24].

There are other genetic markers reported in lipid metabolism associated with diabetes, as Hind III and p.S447X from LPL gene (Lipoprotein lipase) [25]. The BGLAP gene encoding by osteocalcin also was studied. A preliminary report on a population of Western of México reveals that polymorphism $-180 \mathrm{C} / \mathrm{T}$ has been associated [26]. Also found positive for mutations in hIAPP gene (which encodes for amyloid polypeptide) in diabetics from Western of Mexico [27]. In these screening studies there are no variants associated in southeast and central population in HNF1 $\beta$, INS, NeuroD1 genes $[28,29]$.

Our preliminary studies in a population from the Western of Mexico, found association with polymorphism in the locus g.37190613 of ELMO1, as well as long alleles of repeated (CAG)n sequence in ATXN2. The first regulates expression of extracellular matrix as switching occurs in cases with mutations for the lamin $\mathrm{A} / \mathrm{C}$ gene, who have diabetes. However deficiency of ATXN2, which is crucial in neurogenesis, lead to insulin resistance, obesity, liver fat and dislipidemia [30,31]. These results will have to be corroborated and replicate in México as well as other countries.

In México, the pharmacogenetic studies are limited. Carriers heterozygous genotype for SNP43 of CPN10 patients from Merida Yucatán Mexican (southeast), are associated with poor response to sulfonylurea and metformine treatment [32]. While heterozygote p.R230C diabetic patients from México City, requires a higher dose of glyburide in order to achieve the same glucose lowering effect as that observed in patients who have the wild type p.R230R [13].

The genome-wide scan with 9.2 million single nucleotide polymorphisms (SNPs) in each of 8,214 Mexicans and other Latin Americans, identified a novel locus associated with T2DM, SLC16A11 also SLC16A13 [33]. The association was stronger replicated in independent samples. Also non-synonymous rs4994 polymorphism of the $A D R B 3$ gene was associated with $\mathrm{T} 2 \mathrm{D}$ (Trp allele, $\mathrm{OR}=0.62$, $\mathrm{p}=0.001)$ in probands from Mexico City [34].

In long samples of Mexico City, a single rare missense variant c. $1522 \mathrm{G}>\mathrm{A}$ in the gene HNF1A (hepatic nuclear factor 1- $\alpha$ ), was associated with type 2 diabetes prevalence, $\mathrm{OR}=5.48$ [35].

In Western population, IL-6 -598/-572/-174 (AGC) haplotype has a low prevalence among first-degree relatives of subjects with type 2 diabetes, and it is associated with decreased risk in Mexican subjects with familial history T2DM [36].

Recently, also in diabetics probands without coronary complications but hypertension from Western of México, were reported association with the $14 \mathrm{bp}$ del/Ins HLA-G polymorphism, particularly to Ins/Ins carriers [37].

In a comprehensive study, examination of twenty-four single nucleotide polymorphisms (SNPs), previously associated with T2DM, were analyzed in 1,027 Mexican Mestizos. Genes; KCNJ11, PPARG, TCF7L2, SLC30A8, HHEX, CDKN2A/2B, CDKAL1, IGF2BP2, ARHGEF11, JAZF1, CDC123/CAMK1D, FTO, TSPAN8/LGR5, KCNQ1, THADA, ADAMTS9, NOTCH2, NXPH1, RORA, UBQLNL and RALGPS2, an Association to type 2 diabetes was found for rs 13266634 (SLC30A8), rs7923837 (HHEX), rs10811661 (CDKN2A/2B), rs4402960 (IGF2BP2), rs12779790 (CDC123/CAMK1D), and rs2237892 (KCNQ1). In addition the SNP rs7903146 (TCF7L2) was observed associated for early-onset type 2 diabetes [38].

Another cohort of 519 subjects with T2DM from Mexico City they analyzed the association of 14 polymorphisms located within 10 genes (candidate gene for metabolic syndrome), and they discarded the role of ENPP1, KCNJ11, LEPR, PPAR gamma, FTO, CDKAL1, SIRT1 and HHEX. In this report TCF7L2 and ADRB3 has stronger association [39].

Previous association studies found important molecular heterogeneity of T2DM in Mexico. There are still more genes to explore, and this is expected due to the complex nature and the polygenic component of this were the polygenic component of this trait where its threshold is modulated by environmental factors. Therefore more studies required replica, as performed in case-control studies in the state of Guerrero and in Mexico City, with 400 subjects from Guerrero and 1065 from Mexico City. Heterozygote for the Gly972Arg variant of the IRS1 gene showed the strongest association for T2DM in both analyzed samples. In addition, an association of two SNPs of the TCF7L2 gene was observed in both cities: rs7903146, (for Guerrero OR=1.98 and for Mexico $\mathrm{OR}=1.94)$ and $\mathrm{rs} 12255372(\mathrm{OR}=1.79, \mathrm{OR}=1.78$ respectively). These results suggest that variation in the IRS1 and TCF7L2 genes confers susceptibility in our studied populations [40].

Therefore the familiar physician at first level of care should consider for clinical evaluation the following items: the genetic profile which included SNP for diabetes replicated and validated polymorphisms for pharmacological control, CPN10 SNP43 and heterozygous for the codon 203 of the $A B C A 1$ gene determination as previously cited $[13,32]$.

\section{Molecular Heterogeneity in Chronic Complications at Mexican Population}

Chronic complications are those related to development of microangiopathy, such as retinopathy and diabetic nephropathy. Both are also considered as complex traits with threshold similar to that of T2DM $[1,2]$. Different metabolic pathways are altered and its dysfunction leads to the development of these complications. The most common affected ways are the polyol pathway, inflammation and vascular dysfunction, rennin angiotensin aldosterone system, and dyslipidemia among others. We analyze in this paper two kind of chronic; the ophthalmological and renal complication.

\section{Ophthalmological Disease}

In Mexican population, studies have focused on finding genetic markers for predisposition of T2DM; Such as genes related to polyol pathway, dyslipidemia and antigen presentation. There have been various studies in relation to retinopathy and diabetic ophthalmopathy like macular edema. This last, in populations from Western, are associated to the allele E4 from APOE gene [41]. Also, some studies found association between heterozygous genotype from the polymorphism p.207S of CYP19A1 gene and moderate macular edema in diabetic patients [23].

Besides, association in diabetic retinopathy to ALR2 gene (encodes for aldose reductase) was found. Carriers with repeats longer than 23 from the polymorphism (AC)n, show a risk of 5.16. This suggests that long allele's carriers for this genetic marker are at increased odds ratio [42].

On the other hand, It was reported a protective factor for retinopathy in Mexican Mestizos with diabetes over 10 years of evolution; the gene HLA- $R 7$ finds odds less than one unit [43].

Finally in relation to diabetic ophthalmological disease, it has been found association between proliferative retinopathy with the genotypes Arg64Arg Trp64Arg from gene encoding for adrenergic beta receptor type 3 in Western population of México [44]. 
Citation: Flores-Alvarado LJ, Ramirez-Garcia SA, Ferman PD, Davalos-Rodriguez NO, Chavéz-Lopez C, et al. (2014) Molecular Heterogeneity of Type 2 Diabetes Mellitus in Mexican Population and its Impact of the Public Health on Policies in Primary Care. Med chem 4: 791-790. doi:10.4172/2161-0444.1000232

Previous studies show some candidate genes but as we mentioned in the manuscript, the T2DM and its complications are a complex traits, both in diabetic eye disease a single gene or genetic variant cannot explain the risk of development which actually is expected. Studies will be needed also at the interaction gene-gene and gene-environment.

\section{Renal Disease}

Studies of candidate genes in relation to the predisposition to the development and progression of kidney disease are limited in the Mexican population. In this sense we have been explored classic metabolic pathways such as vascular function and closely linked rennin angiotensin aldosterone system, which used some molecular markers [2]. In a town from central of México, a study shows, association between albuminuria and mutant alleles of BstxI or ScaI from $h A N P$ gene; odds ratio of 0.60 and 0.51 , suggesting that protective factors are implicated. Another study from central and of western of México population shows that the homozygous genotype D or I from ACE gene, are associated with incipient nephropathy and established kidney disease with odds ratios greater than 2.8 [45-47].

There are other preliminary studies with markers encoding proteins for the glomerular filtration barrier genes in the West population, including the HPSE, LRP2 y CUBN genes, which encodes heparanase, low density lipoprotein receptor-related protein 2 and cubilin. HPSE is necessary for maintaining homeostasis of heparan sulfate at the basal lamina [48].

LRP2 and CUBN products of translation regulate proteins participating in endocytosis at the brush border epithelium of proximal tubule. In the case of gene HPSE we analyzed the polymorphism p.K307R in subjects with established nephropathy, but just have found an overdominant effect on T2DM, and not with renal disease. However it has been explored, considering that one have to increase the population sample and corroborate in other population. Because this genetic marker has a locus at the region encoded by active site of the heparanase [48], it should be explored. Physicians at first level should be clear that when a gene is mapped and has variants in regions coding for functional domains, these markers must be considered as a candidate for association studies. Thus variations such as that can be translated into different functional isoforms, which may have relation to the development of the phenotype; the kidney could have dysfunction at the basal lamina.

For LRP2, we analyzed the polymorphisms p.H498Q in locus at exon 22 and p.R4220P as p.I4210L located at the exon 69. The polymorphism in exon 22 is not associated with overt nephropathy, but has an overdominant effect on T2DM. Variations at exon 69 haplotype were constructed by Azuma algorithm, resulting than the haplotype 2-2 (CC-CC), has a risk factor of 13.5 [49,50].

The variants p.I2984V (rs1801239) and p.G3002E (rs1801240) of CUBN gene was also analyzed in overt diabetic nephropathy in a Mexican preliminary cohort. The first p.2984V resulted been a polymorphism, but do not be in Hardy Weinberg equilibrium, and has no ancestral homozygous $G$ genotype. The second marker resulted in an allelic variant (mutation) in the Mexican, as just the A allele (p.G) was found in the analyzed population. The polymorphism p.I2984V (rs1801239) is not associated with diabetic nephropathy, but it presents association to T2DM [51]. Now a recent meta-analysis described an rs1801239 (p.Ile2984Val) associated with albuminuria levels both in the general population and in diabetics. Also, this polymorphism is part of a larger haplotype in European populations and it is almost absent in West Africans. This haplotype contains 19 (SNPs) in very high Linkage disequilibrium, three of them are missense mutations (p.Leu2153Phe,
p.Ile2984Val, p.Glu3002Gly), and two have not been previously reported [52]. In donor from renal transplantation rs7918972 was associated with elevated proteinuria levels cross-sectionally at one year after transplantation. Thus, we identified as a novel risk variant for renal function loss in two independent settings. ESRD in native kidneys and transplanted kidneys graft failure [53]. The exome sequencing of the CUBN gene shows correlation with proteinuria [52]. Thus we must replicate in Mexican population with a larger number of probands included.

\section{Implications for the Public Health Care Policies}

Undoubtedly the genomic medicine is a new paradigm in the field of public health as well as in the first level of health care. The vision and expectations of both disciplines and researchers are quite different. Recently a study was conducted in which the perspectives on genomic medicine (GM) and its consequences in the decision-making process regarding to the health policy in Mexico were explored, during the II National Congress of GM (October 2006). Some researchers believe that the 3P's of GM (Predictive, Personalized, and Preventive) have generated inflated expectations on the real impact on public health $(\mathrm{PH})$. Opinions were divided but in our experience in clinical practice leads we to believe that GM is the new paradigm of $\mathrm{PH}$, where a set of tools for explain the health-disease process can be used [54,55]. In this sense, polymorphisms as genetic markers may be medical indicators of predictive, personalized, and preventive medicine, but improving health conditions of the Mexican population, also, must be part of the solution of $\mathrm{PH}$ problems. We need a realistic view of the rulers to get the resources and infrastructure needed throughout.

In summary, the great ethnic diversity of Mexico, the public policies, the fine-scale patterns of human genome-wide variation from each region, is critical for medical studies, which translates in different degrees of susceptibility [56]. The genetic heterogeneity observed in T2DM Mexican people, is specific to that population, but studies need to be replicated. There are not common structures of genetic susceptibility in México, because this country has a high genetic diversity and each zone has their own genomic structure depending of the ethnic group studied. More studies will be realized for exploring this lines research.

Therefore it is important for the governments provide the money needed for carried out the genetic profiles of patients with diabetes mellitus, to save costs in health care, to find individuals at high risk, to find new predisposing factors for progression of the disease, and also to establish the response to drug treatment. Mexican government through its hospitals; federal government, state or municipalities, have the responsibility to care for its population. Detecting hyporesponders, allow physicians to seek alternative treatment options in order to optimize treatment and reduce costs to municipalities to health care. In this sense, genomic medicine is an important tool in Mexican population. At least one can include well-validated markers in genetic studies as is the case CPN10, ABCA1, TCF7L2, SLC16A11, ADRB3, IRS, hANP, ATXN2, ELMO1, and ACE. It is necessary for each population and even each ethnic group to identify their genetic risk markers. Governments at different levels must work on establishing preventive measures in order to detect vulnerable groups with risk factors and reduce costs in health care as a consequence of that policy. In this work, we provide an insight about which studies must be conducted at the molecular genetics level $[30,31]$.

Heterogeneity of risk factors in Mexican population is important and government must take into account as part of its public policy. Implications for genomic medicine in States, Towns and municipal government are of paramount importance considering the impact 
Citation: Flores-Alvarado LJ, Ramirez-Garcia SA, Ferman PD, Davalos-Rodriguez NO, Chavéz-Lopez C, et al. (2014) Molecular Heterogeneity of Type 2 Diabetes Mellitus in Mexican Population and its Impact of the Public Health on Policies in Primary Care. Med chem 4: 791-790. doi:10.4172/2161-0444.1000232

of specific markers according to the region studied. Policies at the municipalities of México must include genetic profiles of CPN10, $A B C A 1$, which allow identifying poor responders to treatment, due to glibenclamide/merformin as glyburide, are the most prescribed drugs $[13,32]$.

In conclusion, the complexity of DM lies in the overlap with other forms of diabetes, its association with cardiovascular risk factors, as well as its variable expressivity and heterogeneity of molecular mechanisms involved. The molecular heterogeneity of type 2 diabetes in the Mexican population is specific; it is related to the degree of mixing that occurred during the conquest. Also associated with this genetic diversity, which translates into differences in clinical presentation and in epidemiological rates, it is necessary more studies or types the replica and association with genetic markers that were presented. The use of the public as part of these policies will be basic for a more personalized treatment for diabetics, also to prevent or predict the development of chronic complications generating high costs for their attention to governments.

\section{Acknowledgement}

By Financing to PROMEP-SEP, Release letter 103-5/12/4528 and Support for Strengthening the Academic Group (UNISIS-CA-10 Biochemistry Applied to health) with IDCA11337. To Luis J. Flores, MD, native translator and speaker, by the support in translating the manuscript.

\section{References}

1. Ramirez-Garcia SA, Cabrera-Pivaral CE, Huacuja-Ruiz L, Flores-Alvarado LJ, Pérez-García G, et al. (2013) [Implications in primary health care of medical genetics and genomic in type 2 diabetes mellitus]. Rev Med Inst Mex Seguro Soc 51: e6-26.

2. Rosales-Gómez RC, López-Jiménez Jde J, Núñez-Reveles NY, GonzálezSantiago AE, Ramírez-García SA (2010) [Type 2 diabetes nephropathy: a thresholds complex trait and chromosomal morbid map]. Rev Med Inst Mex Seguro Soc 48: 521-530.

3. Carrillo C, Panduro A (2001) Genética de la diabetes mellitus tipo 2. Investigación en Salud 3: 27-34.

4. Suzuki S, Makita Y, Mukai T, Matsuo K, Ueda O, et al. (2007) Molecular basis of neonatal diabetes in Japanese patients. J Clin Endocrinol Metab 92: 3979-3985.

5. Pociot F, McDermott MF (2002) Genetics of type 1 diabetes mellitus. Genes Immun 3: 235-249.

6. Freeman H, Cox RD (2006) Type-2 diabetes: a cocktail of genetic discovery. Hum Mol Genet 15 Spec No 2: R202-209.

7. Quintanilla-García C, Zúñiga-Guajardo S (2010) [The incretin effect and type 2 diabetes]. Rev Med Inst Mex Seguro Soc 48: 509-520.

8. Cook JT, Hattersley AT, Levy JC, Patel P, Wainscoat JS, et al. (1993) Distribution of type II diabetes in nuclear families. Diabetes 42: 106-112.

9. Maassen JA, Kadowaki T (1996) Maternally inherited diabetes and deafness: a new diabetes subtype. Diabetologia 39: 375-382.

10. García-García E, Aguilar-Salinas CA, Tusié-Luna T, Rull-Rodrigo JA (2002) Early-onset type 2 diabetes in Mexico. Isr Med Assoc J 4: 444-448.

11. Tack CJ, Ellard S, Hattersley AT (2000) A severe clinical phenotype results from the co-inheritance of type 2 susceptibility genes and a hepatocyte nuclear factor-1alpha mutation. Diabetes Care 23: 424-425.

12. Villarreal-Molina MT, Flores-Dorantes MT, Arellano-Campos O, VillalobosComparan M, Rodríguez-Cruz M, et al. (2008) Association of the ATP-binding cassette transporter A1 R230C variant with early-onset type 2 diabetes in a Mexican population. Diabetes 57: 509-513.

13. Aguilar CA, Muñoz LL, Cobos M, Ramírez MR, Ordoñez ML, et al. (2013) The R230C variant of the ATP binding cassette protein A1 (ABCA1) geneis associated with a decreased response to glyburide therapy in patients with type 2 diabetes mellitus. Metabolism 62: 638-641.

14. del Bosque-Plata L, Aguilar-Salinas CA, Tusié-Luna MT, Ramírez-Jiménez S, Rodriguez-Torres M, et al. (2004) Association of the calpain-10 gene with type 2 diabetes mellitus in a Mexican population. Mol Genet Metab 81: 122-126.
15. Salgado L, Cobian J, García A, Machorro V, Cruz E, et al. (2006) Association of polymorphisms SNP19 and SNP63 of capain 10 gene in patients with type 2 diabetes mellitus. Report of the meeting of the study group of diabetes mellitus A.C. (16 stedn). Guadalajara, Jalisco, México.

16. Gomez TJ, Carrillo C, Godínes S, Gonzalez M (2005) The GG genotype of SNP43 of CAPN10 gene polymorphism is associated with type 2 diabetes mellitus Jaliscience population. Report of the Scientific Research Week. (16 stedn). Universidad de Guadalajara, Jalisco, México.

17. Parra EJ, Cameron E, Simmonds L, Valladares A, McKeigue P, et al. (2007) Association of TCF7L2 polymorphisms with type 2 diabetes in Mexico City. Clin Genet 71: 359-366.

18. Cameron EA, Martinez-Marignac VL, Chan A, Valladares A, Simmonds LV, et al. (2007) MGEA5-14 polymorphism and type 2 diabetes in Mexico City. Am J Hum Biol 19: 593-596.

19. Gutiérrez-Vidal R, Rodríguez-Trejo A, Canizales-Quinteros S, HerreraCornejo M, Granados-Silvestre MA, et al. (2011) LOC387761 polymorphism is associated with type 2 diabetes in the Mexican population. Genet Test Mol Biomarkers 15: 79-83.

20. Burguete-Garcia Al, Cruz-Lopez M, Madrid-Marina V, Lopez-Ridaura R, Hernández-Avila M, et al. (2010) Association of Gly972Arg polymorphism of IRS1 gene with type 2 diabetes mellitus in lean participants of a national health survey in Mexico: a candidate gene study. Metabolism 59: 38-45.

21. Ruiz B, Godínez SA, Nuño GP, Panduro A (2001) Genetic polymorphism of apolipoprotein $E$ associated to type 2 diabetes mellitus in mexican population. Diabetología 44: A91.

22. Guzmán-Flores JM, Muñoz-Valle JF, Sánchez-Corona J, Cobián JG, MedinaCarrillo L, et al. (2011) Tumor necrosis factor-alpha gene promoter -308G/A and -238G/A polymorphisms in Mexican patients with type 2 diabetes mellitus. Dis Markers 30: 19-24.

23. Martín MB, Herón PM, Sánchez HP, Enciso AE, Sandoval GF, et al. (2011) Asociación del polimorfismo T188G en el gen del transportador lipidito CD36 con diabetes mellitus tipo 2 en mestizos mexicanos del occidente de México. Archivos de Ciencia 3: 21.

24. Sandoval CL, Chávez HK, González M, Carrillo C (2005). Genetic variation in the gene for aromatase haplotypes disclosed by different enzyme isoforms which encode. Report of the Scientific Research Week. (15 stedn). Universidad de Guadalajara, Jalisco, México.

25. Muñoz-Barrios S, Guzmán-Guzmán IP, Muñoz-Valle JF, Salgado-Bernabé AB, Salgado-Goytia L, et al. (2012) Association of the Hindlll and S447X polymorphisms in LPL gene with hypertension and type 2 diabetes in Mexican families. Dis Markers 33: 313-320.

26. Villafán JR, Sánchez S, Llamas CM, Guzmán P, Muñoz JF (2011) El polimorfismo Hind III-180 C/T, nuevo marcador de susceptibilidad para diabetes mellitus tipo 2. Archivos de Ciencia 3: 53.

27. Garcia-Gonzalez CL, Montoya-Fuentes H, Padilla-Rosas M, Sanchez-Corona $J$ (2007) Amylin S20G mutation in Mexican population. Diabetes Res Clin Pract 76: 146-148.

28. Sánchez-Corona J, Flores-Martínez SE, Machorro-Lazo MV, GalavizHernández C, Morán-Moguel MC, et al. (2004) Polymorphisms in candidate genes for type 2 diabetes mellitus in a Mexican population with metabolic syndrome findings. Diabetes Res Clin Pract 63: 47-55.

29. Domínguez-López A, Miliar-García A, Segura-Kato YX, Riba L, Esparza-López $\mathrm{R}$, et al. (2005) Mutations in MODY genes are not common cause of early-onset type 2 diabetes in Mexican families. JOP 6: 238-245.

30. Topete LR, Ramirez SA, Mazariegos MA, Charles NC, Cruz BJ, et al. (2014) Polimorfismo en el locus g.37190613 del gen ELMO1 y el desarrollo de diabetes mellitus tipo 2: implicaciones en las políticas públicas municipales de salud. Archivos de Ciencia 6(S1):15.

31. Garcia MC, Dávalos NO, Flores LJ, García CD, Cruz BJ, et al. (2014) Epidemiología genética para el polimorfismo (CAG)n de ATXN2 en Población con diabetes mellitus tipo 2 y su impacto en las políticas de salud en la población mexicana. Archivos de Ciencia 6(s1):169.

32. García-Escalante MG, Suárez-Solís VM, López-Avila MT, Pinto-Escalante Ddel C, Laviada-Molina H (2009) [Effect of the Gly972Arg, SNP43 and Prol2Ala polymorphisms of the genes IRS, CAPN10 and PPARG2 on secondary failure to sulphonylurea and metformin in patients with type 2 diabetes in Yucatán, México]. Invest Clin 50: 65-76. 
Citation: Flores-Alvarado LJ, Ramirez-Garcia SA, Ferman PD, Davalos-Rodriguez NO, Chavéz-Lopez C, et al. (2014) Molecular Heterogeneity of Type 2 Diabetes Mellitus in Mexican Population and its Impact of the Public Health on Policies in Primary Care. Med chem 4: 791-790. doi:10.4172/2161-0444.1000232

33. SIGMA Type 2 Diabetes Consortium, Williams AL, Jacobs SB, Moreno-Macías $\mathrm{H}$, Huerta-Chagoya A, et al. (2014) Sequence variants in SLC16A11 are a common risk factor for type 2 diabetes in Mexico. Nature 506: 97-101.

34. Cruz M, Valladares-Salgado A, Garcia-Mena J, Ross K, Edwards M, et al. (2010) Candidate gene association study conditioning on individual ancestry in patients with type 2 diabetes and metabolic syndrome from Mexico City. Diabetes Metab Res Rev 26: 261-270.

35. SIGMA Type 2 Diabetes Consortium, Estrada K, Aukrust I, Bjørkhaug L, Burtt $\mathrm{NP}$, et al. (2014) Association of a low-frequency variant in HNF1A with type 2 diabetes in a Latino population. JAMA 311: 2305-2314.

36. Zamora-Ginez I, García-Zapién AG, Flores-Martínez SE, Sánchez-Corona J, Baez-Duarte BG, et al. (2013) Low prevalence of interleukin-6 haplotypes associated with a decreased risk of type 2 diabetes in Mexican subjects with a family history of type 2 diabetes. Arch Med Res 44: 529-534.

37. García-González IJ, Valle Y, Rivas F, Figuera-Villanueva LE, Muñoz-Valle JF, et al. (2014) The $14 \mathrm{bp} \mathrm{Del/Ins} \mathrm{HLA-G} \mathrm{polymorphism} \mathrm{is} \mathrm{related} \mathrm{with} \mathrm{high} \mathrm{blood}$ pressure in acute coronary syndrome and type 2 diabetes mellitus. Biomed Res Int 2014: 898159.

38. Gamboa-Meléndez MA, Huerta-Chagoya A, Moreno-Macías $H$, VázquezCárdenas P, Ordóñez-Sánchez ML, et al. (2012) Contribution of common genetic variation to the risk of type 2 diabetes in the Mexican Mestizo population. Diabetes 61: 3314-3321.

39. Cruz M, Valladares-Salgado A, Garcia-Mena J, Ross K, Edwards M, et al. (2010) Candidate gene association study conditioning on individual ancestry in patients with type 2 diabetes and metabolic syndrome from Mexico City. Diabetes Metab Res Rev 26: 261-270.

40. Martínez-Gómez LE, Cruz M, Martínez-Nava GA, Madrid-Marina V, Parra E, et al. (2011) A replication study of the IRS, CAPN10, TCF7L2, and PPARG gene polymorphisms associated with type 2 diabetes in two different populations of Mexico. Ann Hum Genet 75: 612-620.

41. Santos A, Salguero ML, Gurrola C, Muñoz F, Roig-Melo E, et al. (2002) The epsilon 4 allele of apolipoprotein $E$ gene is a potential risk factor for the severity of macular edema in type 2 diabetic Mexican patients. Ophthalmic Genet 23: 13-19.

42. Carrillo C, Gonzalez M, Santos A. (2006). AC polymorphism gene for aldose reductase and susceptibility to diabetic retinopathy in patients with type 2 diabetes mellitus. Report of the meeting of the study group of diabetes mellitus A.C. (16 stedn). Guadalajara, Jalisco, México.

43. Quiroz-Mercado $H$, Suárez-Licona A, Fromow-Guerra J, López-Carasa G Cárdenas-Hernández R, et al. (2002) Human lymphocyte antigen DR7 protects against proliferative retinopathy with type II diabetes mellitus. Arch Med Res 33: $123-127$

44. Muñoz JF, Santos A, Vázquez M, Carrillo C, Bastidas B, Ruiz B, et al (2001)
Genotipos del receptor b3-adrenérgico en pacientes con retinopatía diabética no proliferativa y su influencia sobre el perfil de lípidos en el Occidente de México. Rev Mex Patol Clin 48: 07-16.

45. Nannipieri M, Posadas R, Williams K, Politi E, Gonzales-Villalpando C, et al (2003) Association between polymorphisms of the atrial natriuretic peptide gene and proteinuria: a population-based study. Diabetologia 46: 429-432.

46. Palomo-Piñón $S$, Gutiérrez-Rodríguez ME, Díaz-Flores $M$, Sánchez-Barrera $\mathrm{R}$, Valladares-Salgado A, et al. (2009) DD genotype of angiotensin-converting enzyme in type 2 diabetes mellitus with renal disease in Mexican Mestizos. Nephrology (Carlton) 14: 235-239.

47. Ortega-Pierres LE, Gómez García A, Rodríguez-Ayala E, Figueroa-Núñez $\mathrm{B}$, Farias-Rodríguez VM, et al. (2007) [Angiotensin-1 converting enzyme insertion/deletion gene polymorphism in a Mexican population with diabetic nephropathy]. Med Clin (Barc) 129: 6-10.

48. Ramirez SA, Carrillo C (2009) Detección molecular de una variante en la secuencia del gen HPSE que codifica para el dominio del sitio activo de heparanasa y el desarrollo de insuficiencia renal en pacientes con Diabetes mellitus tipo 2. Bioquimia 34: 58.

49. Carrillo C, González-Pinedo Manuel, Ramirez SA (2009) Detección molecular de una variante de secuencia del gen que codifica para megalina y el desarrollo de insuficiencia renal causada por diabetes mellitus tipo 2. Bioquimia 34: 59

50. Carrillo C, Barajas L, García G, Godínez S (2006) Haplotype of megalin gene and the susceptibility by diabetic nephropathy in Jalisciense population. XVI National meeting of the Group study of diabetes mellitus A.C.

51. Carrillo C, González M, Godínez S (2007) Detección molecular de variantes de secuencia del gen que codifica para cubilina y el desarrollo de insuficiencia renal causada por diabetes mellitus tipo 2. Bioquimia 32: 73.

52. Tzur S, Wasser WG, Rosset S, Skorecki K (2012) Linkage disequilibrium analysis reveals an albuminuria risk haplotype containing three missense mutations in the cubilin gene with striking differences among European and African ancestry populations. BMC Nephrol 31:13:142.

53. Reznichenko A, Snieder H, van den Born J, de Borst MH, Damman J, et al (2012) CUBN as a novel locus for end-stage renal disease: insights from renal transplantation. PLoS One 7: e36512.

54. Ovunc B, Otto EA, Vega-Warner V, Saisawat $P$, Ashraf $S$, et al. (2011) Exome sequencing reveals cubilin mutation as a single-gene cause of proteinuria. $J$ Am Soc Nephrol 22: 1815-1820.

55. Oliva-Sánchez PF, Siqueiros-García JM, Vázquez-González JR, SaruwatariZavala G, Carnevale A (2013) [Genomic medicine in public health policies: a perspective of Mexican biomedical researchers]. Salud Publica Mex 55: 16-25.

56. Moreno-Estrada A, Gignoux CR, Fernández-López JC, Zakharia F, Sikora M, et al. (2014) Human genetics. The genetics of Mexico recapitulates Native American substructure and affects biomedical traits. Science 344: 1280-1285. 